\title{
The Mediating Role of Work Engagement in Relationship between Workplace Fun and Meaning of Work toward Job Satisfaction of Millennial Worker in Banda Aceh City
}

\author{
*Hasna Lathifah, Hafasnuddin, Sofyan \\ Management Department, Universitas Syiah Kuala, Indonesia \\ DOI - http://doi.org/10.37502/IJSMR.2021.4516
}

\begin{abstract}
The goal of this study is to examine and analyze the direct effect of workplace fun and the meaning of work toward job satisfaction and the indirect effect of workplace fun and the meaning of work toward job satisfaction through work engagement. The population was the millennial workers in Banda Aceh city, Indonesia, and the sample was taken with purposive sampling technique. There was a total of 203 online questionnaires collected. This research used the structural equation modeling (SEM) method to process and analyze the data, and the findings are: (i) workplace fun has no significant effect on work engagement, (ii) meaning of work significantly affects work engagement, (iii) workplace fun significantly affects job satisfaction, (iv) meaning of work does not significantly affect job satisfaction, (v) work engagement has a significant effect on job satisfaction, (vi) work engagement does not mediate in explaining the effect of workplace fun on job satisfaction, and (vii) work engagement becomes a full mediation in explaining the effect of meaning of work on job satisfaction. So from these results, we can conclude that the model of increasing job satisfaction is a function of increasing work plan fun and work engagement which will directly affect the increase in job satisfaction and the function of increasing meaning of work which will indirectly affect job satisfaction through work engagement. Academically, this model can be developed by further researchers by adding moderating variables such as age or working experience. They can also see a difference between millennials living in urban and rural areas.
\end{abstract}

Keywords: Workplace Fun, Meaning of Work, Work Engagement, Job Satisfaction.

\section{Introduction}

Since 2017, Indonesia has been experiencing a bonus demographic for its population. This is stated in a book published by the Ministry of Women and Children Empowerment in collaboration with the Central Statistics Agency (BPS) in 2018. The organization stated that the demographic bonus phenomenon will only occur once in the nation's history. The demographic bonus is stated by the number of productive age population that fulfills $2 / 3$ of the total 
population. The National Population and Family Planning Agency (BKKBN) explained that the peak of the demographic bonus in Indonesia will occur in 2020-2030, which is marked by the dominance of the working force age 15-64 years as much as 70 percent of the total population. If it can be managed properly, then this demographic bonus should help and increase the country's economic growth (Budiati et al., 2018)

The demographic bonus can also be shown in the number of millennials in Indonesia. Many experts have different opinions regarding the age range of the millennial generation but millennial workers in this study will refer to the Indonesian Millennial Generation Profile book, namely the group of people born in 1980 to 2000. The average percentage of the millennial generation in Indonesia is $33,75 \%$ in 2017 . Aceh Province has a slightly larger percentage of distribution than the Indonesian average of $35.92 \%$. Numerically, the total distribution of the millennial generation in Aceh is 1.8 million people. However, because the distribution of the millennial generation is centered in urban areas, this research will focus on the millennial generation in Banda Aceh City (Budiati et al., 2018).

The term millennial is also known as "Generation Me," "Digital Natives," and Generation Y." This designation is based on their perspective which focuses on individual development and technology literacy. Millennial workers are predicted to dominate employment by 35\% by 2020 (Aleksić \& Rangus, 2020) From the job perspective, Galup in (Budiati et al., 2018) explained millennial workers focus on their work goals, want jobs that can make them grow, don't like a supervisor who likes to command, want conversations to continue, and interpret work as a part of their life. Meanwhile, (Aleksić \& Rangus, 2020) added the characteristics of workplace expectations desired by millennials, namely work-life balance, meaningfulness, challenges, job crafting, and entertainment. All of these characteristics then become part of the workplace fun and meaning of work variables. There are not many studies that discuss millennial workers so that researchers are interested in making this a variable part of the characteristics in this study.

Workplace fun or defined as a pleasant workplace is a workplace concept that is considered important by workers under the age of 30 (Fluegge-Woolf, 2014). Since thirty years ago, the concept of a pleasant workplace is considered to have a positive effect on workers and organizations through increasing motivation and productivity (Becker \& Tews, 2016). A pleasant workplace is further defined as an attractive workplace condition, can interact with each other, interpersonal, has a recreational side, and other activities that make the work environment more attractive (Tsaur, Hsu, \& Lin, 2019).

Several studies have been able to show the benefits of implementing workplace fun. First, job satisfaction (Karl \& Peluchette, 2006) in (Tsaur et al., 2019). Workers can feel satisfied with their work when they are in a pleasant environment (Chan \& Mak, 2016). Workplace fun is also considered to have an influence on work engagement for workers. Deal and Kennedy revealed that if the company provides a pleasant place to work, employees will carry out their work wholeheartedly. (Schaufeli, Bakker, \& Salanova, 2006) define work engagement as a 
psychological condition of feeling positive and satisfied with work so that worker feels dedicated and enthusiastic in work (Fluegge-Woolf, 2014).

To find out whether millennial workers in Banda Aceh have or have not felt their attachment to their work, the researcher conducted a preliminary survey. The results show that, on average, millennials agree that they are engaged with their jobs. Numerically, from each dimension of work engagement, $66.7 \%$ of respondents agree that they feel ready to work in the morning, $76.7 \%$ of respondents feel enthusiastic about their work, and $80 \%$ of respondents have been involved with their work.

In the world of work, the millennial more prone to leave the job if the job is not going according to what they expect. They want meaningful work because work is a form of achieving self-realization (Jung \& Yoon, 2016). Meaning of work describes as a job situation that is greater than the value of job satisfaction because it involves three levels of satisfaction, namely intrinsic, extrinsic, and deeper levels (Wong, Wan, \& Gao, 2017).

From the results of the pre-survey, almost all respondents agree that work is important for their lives. $70 \%$ of workers agree that the good name of their work has been felt for them. This shows the pride of having a good reputation at work. This is followed by the feeling that work is satisfying and important and paycheck is important as much as $66.7 \%$ and the value of work is $63.3 \%$ and relationships with coworkers $56.7 \%$.

The meaning of work also plays an important role in job involvement. (Geldenhuys, Łaba, \& Venter, 2014) stated that the meaning of work has an impact on a good performance. Workers who mean their work well can adapt to the work environment than those who do not. In the end, this job also gives them job satisfaction towards their company (Jung \& Yoon, 2016).

Research on millennial workers has been done. However, these studies are based solely on their unique characteristics based on general observations. This study gives an overview updated with how a pleasant working environment ( workplace fun ) and the meaning of work ( meaning of work ) play a role in improving their job satisfaction with mediation assistance job involvement ( work engagement).

\section{Literature Review}

\section{Job Satisfaction}

Job satisfaction is considered to be part of the work result. Macey and Schneider revealed that job satisfaction is an emotional result of engagement with work (Yalabik, Rayton, \& Rapti, 2017). (Spector, 1985) defined job satisfaction as a response to an individual's emotional feelings in his perspective on work. (Oshagbemi, 1997) stated that job satisfaction is an emotional response as a result of the relationship between the views of workers and the benefits they get from work.

The dimensions and indicators used in this study are based on a job satisfaction survey conducted by (Spector, 1985), namely (i) the nature of the work with indicators; job meaning, liking work, feeling proud of work, and feeling a pleasant job, (ii) operational conditions with indicators ; regulations and work procedures, amount of work done, and job documents, (iii) 
promotion with indicators; opportunity to get promotion, fairness of promotion, speed of process of getting promotion, and satisfaction with promotion process, (iv) salary with indicator; fairness of salary, difference in salary increase, perspective on salaries, and opportunities for salary increases, (v) supervisory supervisors with indicators; superior competence, fairness of treatment from superiors, superiors' interest in subordinates, and views on superiors, (vi) benefits (nonfinancial) with indicators; satisfaction with benefits, comparison benefits with other organizations, justice with benefits, and facilities the benefits that should be received, (vii) awards with indicators; recognition for hard work, feelings of being appreciated for work, number of awards received, and feelings that the awards received are equivalent to the work that has been done, (viii) colleagues with indicators; views of colleagues work, assessment of incompetent co-workers, friendship with coworkers, and workplace disputes, (ix) communication with indicators; value for communication, communication of company goals, knowledge of what is happening in the company, and job descriptions (Spector, 1985).

\section{Work Engagement}

(Karatepe \& Karadas, 2016) stated work engagement as a motivational concept for workers that involves their psychological feelings towards positive and satisfied feelings. Positive feelings refer to a state of being excited and able to meet work targets (Schaufeli et al., 2006) and (Tsaur et al., 2019). (Schaufeli et al., 2006) believes that this engaged condition is the opposite of the burn-out condition, which is a condition of physical and mental exhaustion due to work in the office (Yalabik et al., 2017). The dimensions and indicators used in this study are based on The Utrecht Work Engagement Scale (UWES). There are seventeen indicators grouped into three dimensions: (i) vigor with indicators; filled with energy, feeling strong and energized, feel ready to work, can work for long periods, tenacious with work, and diligence, (ii) dedication with indicators; finding the meaning and purpose of work, enthusiastic about work, feeling inspired by work, proud of work, and challenges in work, (iii) absorption with indicator; working time, forgetting things that happen when working, feeling happy with intense work, engaging with work, getting carried away with work, difficulty feeling detached from work (Schaufeli et al., 2006).

\section{Workplace Fun}

Workplace fun is a term that introduces the concept of a work environment that involves social elements, interpersonal relationships, and fun activities. Workplace fun gives individuals the freedom to feel happy and enjoy their work (Fluegge-Woolf, 2014). Similar to (FlueggeWoolf, 2014) gave his opinion on the definition of workplace fun is an environment that encourages and supports workers to do fun activities and can have a positive impact on the behavior and productivity of workers as individuals and teams (Clancy \& Linehan, 2019). The dimensions and indicators used in the study are divided into three, namely (i) fun activities with indicators; celebration of work achievements, team cohesiveness activities, competence, celebration of public achievements, and recognition of personal achievements, (ii) social 
relations with colleagues with indicators; mutual respect. sharing stories, joking with each other, making friends in the workplace environment, and making friends outside the workplace environment, (iii) supervisor or manager support with indicators; manager/supervisor support for fun at work, affirmation for fun at work, supervisor effort to make work enjoyable, concern for workers to have fun, and permission to enjoy pleasure in the work environment (Ford, McLaughlin, \& Newstrom, 2003), (Shanock \& Eisenberger, 2006), (Tews, Michel, \& Allen, 2014).

\section{Meaning of Work}

(Hackman \& Oldham, 1980) attribute a job to be meaningful if workers perceive the work as meaningful, valuable, and do not feel that time is wasted when the work is done. (Rosso, Dekas, \& Wrzesniewski, 2010) mention that work can be meaningful if it fulfills these four things if it is involved with self-esteem, work environment, spiritual side, and involvement with others (Akgunduz, Alkan, \& Gök, 2018). The dimensions and indicators in this study are based on the research of (Jung \& Yoon, 2016) which also looked from the research of (Harpaz \& Fu, 2002), namely (i) the centrality of work with indicators; the real meaning of work and the relative importance of work associated with other parts of life, (ii) rights norms with indicators; training opportunities, meaningful work, and rights to be involved with work, (iii) economic orientation with indicators; importance of salary, role of money, and good pay, (iv) interpersonal relationships with indicators; attractive relationships, type of co-workers, good interpersonal relationships, (v) expressive orientation with indicators; satisfactory work, suitability between work and abilities, and interesting work, (vi) norms of obligations with indicators; contribution to society, work roles for the future, and work values (Harpaz \& Fu, 2002) and (Jung \& Yoon, 2016)

\section{Research Method}

\section{Research location and Object}

The data and information used in this study will be obtained from the distribution of online questionnaires. The questionnaire was addressed to millennial workers, i.e. workers born between 1980 and 2000, working in Banda Aceh City, and have been working for a minimum of six months. There are a total of 203 respondents have been chosen, with that purposive sampling method. Furthermore, the object of research was associated with four variables used in this study including workplace fun, meaning of work, work engagement, and job satisfaction.

\section{Data Analysis Tool}

Descriptive analysis in this study was conducted to describe millennial workers' responses to workplace fun, meaning of work, work engagement, and job satisfaction. By using the weighted average score, if the mean score is $\geq 3.41$, it is stated that the research variable has 
been perceived well. The confirmatory factor analysis test on the structural equation model will use the AMOS version 22.

\section{Research Framework and Hypothesis}

The path analysis for the research framework is presented as follows:

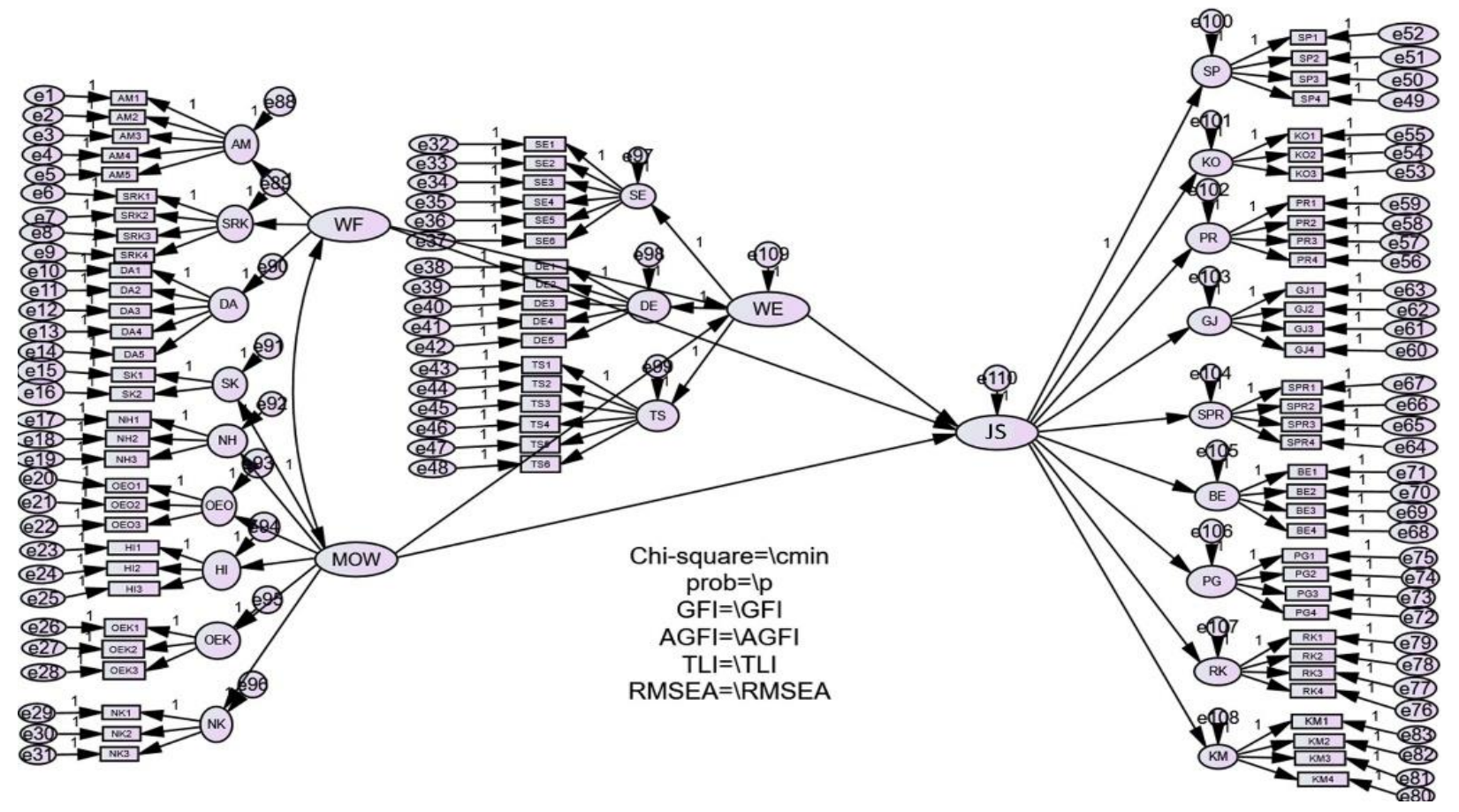

Figure 1. Structural Equation Model

The research Hypothesis that has been determined by the authors is as follows.

Hypothesis 1: Workplace Fun affects Work Engagement

Hypothesis 2: Meaning of Work affects Work Engagement

Hypothesis 3: Workplace Fun affects Job Satisfaction

Hypothesis 4: Meaning of Work affects Job Satisfaction

Hypothesis 5: Work Engagement affects Job Satisfaction

Hypothesis 6: The Mediating Role of Work Engagement in the Effect of Workplace Fun toward Job Satisfaction

Hypothesis 7: The Mediating Role of Work Engagement in the Effect of the Meaning of Work toward Job Satisfaction

\section{Result}

\section{Hypothesis 1: The Effect of Workplace Fun on Work Engagement}

The first hypothesis is stated that workplace fun has an effect on work engagement. Based on the test results obtained a P-value of 0.082 ( $p>0.05$ ), so it is stated that $\mathrm{H}_{01}$ is accepted 
and $\mathrm{H}_{\mathrm{a} 1}$ is rejected. This means that workplace fun has no significant effect on work engagement. The estimated value of the direct effect of workplace fun on work engagement is -0.246.

Workplace fun may have no effect on work engagement. Aspects that affect whether a person can have fun at work are shown through management issues. The support of a direct supervisor or manager, as revealed in (Becker \& Tews, 2016), is an important reason to avoid the intention of resigning. This is because dealing with superiors or managers is a routine activity experienced by workers every day so that workers feel they can have fun at work if they get support from their superiors/managers (Georganta \& Montgomery, 2019). Even though it is stated so, it does not mean that management cannot apply this in their work environment. A study proves the efforts of every individual in the company to create a pleasant work environment are still possible and more likely to succeed. Using opinions from previous research, (Bilginoğlu, 2020) revealed that a pleasant workplace can be an important part of the company's culture and trends are assessed every month. In other words, management wisdom is a determining factor that whether may or not a pleasant work environment is allowed because if managers can shape this, then an effective organization including individual workers and work teams can be involved in the long term (Bilginoğlu, 2020).

\section{Hypothesis 2: The Effect of Meaning of Work on Work Engagement}

The second hypothesis stated is the meaning of work affects work engagement. Based on the test results obtained a $\mathrm{P}$-value of 0.001 ( $\mathrm{p}<0.05$ ), so it is stated that $\mathrm{H}_{02}$ is rejected and $\mathrm{H}_{\mathrm{a} 2}$ is accepted. That is, the meaning of work has a significant effect on work engagement. The estimated value of the direct effect on the meaning of work on work engagement is 1.127, which means an increase in the meaning of work by 1 unit will increase work engagement by 1.127.

In (Wong et al., 2017), millennials are looking for a career that gives them selfdevelopment. Information from the results of the study explains they expect their superiors would teach them so that they could do difficult jobs and not be fired from their jobs. The study also describes three aspects that determine how careers can give meaning, namely (i) work as work, (ii) work as a community, (iii) work as part of their work. Perceiving work only as a routine was described by research subjects as boring, stressful, and tiring so that what happened was that they were the most disloyal to their jobs and often sought after-hours solace. Working as part of a community implies that work is meaningful when surrounded by supportive coworkers. This can be demonstrated through celebration and fun so that the workplace is considered a 'second home' and forms a community. Lastly, work as a part of self-being shows the desire of millennial workers to get promotions in career paths. These socio-economic factors then become job motives, how they give meaning to a career, and commitment not only to work but also to employers and their careers (Geldenhuys et al., 2014) and (Wong et al., 2017).

\section{Hypothesis 3: The Effect of Workplace Fun on Job Satisfaction}

The third hypothesis is stated that workplace fun affects job satisfaction. Based on the test results obtained a P-value of 0.015 ( $\mathrm{p}<0.05$ ), it is stated that $\mathrm{H}_{03}$ is rejected and $\mathrm{H}_{\mathrm{a} 3}$ is accepted. This means that workplace fun has a significant effect on job satisfaction. The 
estimated value of the direct effect on workplace fun on job satisfaction is 0.621 , which means an increase in workplace fun by 1 on a unit will increase job satisfaction by 0.621 .

Job satisfaction shows the emotional feeling of the worker from what he does, including the aspects that can affect it. Citing statements from (Luthans, 2002), (Diener, Suh, Lucas, \& Smith, 1999) and (Perrin, 1998) describes how positive emotions from employees impact good organizational behavior. This means, for the organization, providing a pleasant workplace will contribute to life satisfaction, job satisfaction, and the experience of pleasant emotions and moods to increase business profits, lower employee resignation rates, reduce stress due to work problems. More specifically, from the statements submitted to employees, having a comfortable and pleasant work environment increases good results on enthusiasm for work, team cohesiveness, employee satisfaction, employee creativity, friendship at work to reduce internal conflicts at work (Ford et al., 2003).

\section{Hypothesis 4: The Effect of Meaning of Work on Job Satisfaction}

The fourth hypothesis stated that the meaning of work has an effect on job satisfaction. Based on the test results obtained a P-value of 0.258 ( $p>0.05)$, it is stated that $\mathrm{H}_{04}$ is accepted and $\mathrm{H}_{4}$ is rejected. That is, the meaning of work has no significant effect on job satisfaction. The estimated value of the direct effect on the meaning of work on job satisfaction is -0.691 . Millennial is a unique group and wants career choices that suit them. This statement is written from the results of qualitative research on career choices and the meaning of work for the millennial generation. For millennials, the eight main reasons for choosing a career are financial and non-financial benefits, job stability, flexibility, work environment, communication, relationships between supervisors and coworkers, opportunities for self-development and achievement (Wong et al., 2017). Work is considered meaningful if the work is following what is expected. By (Maharaj \& Schlechter, 2007), as quoted by (Zika \& Chamberlain, 1992), meaningful work means giving a higher level of job satisfaction so that they can be more actively involved with work. Therefore, if workers find that a job is not meaningful to them, they should not depend on the employer to fulfill their expectations and seek independently to make sense of the job or look for other jobs that are considered meaningful to increase the satisfaction that they expect (Maharaj \& Schlechter, 2007).

\section{Hypothesis 5: The Effect of Work Engagement on Job Satisfaction}

The fifth hypothesis is stated that work engagement has an effect on job satisfaction. Based on the test results obtained a P-value of 0.011 ( $\mathrm{p}<0.05)$, it is stated that $\mathrm{H} 05$ is rejected and Ha5 is accepted. This means that work engagement has a significant effect on job satisfaction. The estimated value of the direct effect on work engagement on job satisfaction is 1.155, which means an increase in work engagement of 1 Likert scale will increase job satisfaction by 1.155 .

According to (Tsaur et al., 2019), job satisfaction is related to work engagement. (Yalabik et al., 2017) stated that work involvement has a fully positive influence through the 
dimensions of the nature of work. This is following the good response of millennial workers on the dimensions of the nature of work. Then, the influence is partially through operational and communication conditions. These two dimensions are not well received by millennial workers. Meanwhile, the dimensions of promotion, supervisory supervision, and non-financial benefits have no effect. Millennial workers have unique characteristics such as not wanting a job with difficult procedures, wanting a promotion in a career path that makes them grow, and two-way communication with superiors and coworkers. This characteristic has also been stated in the research questionnaire and has an influence between job involvement and job satisfaction.

\section{Hypothesis 6: The Mediating Role of Work Engagement in relationship Between Workplace Fun toward Job Satisfaction}

The sixth hypothesis stated in workplace fun has an indirect effect on job satisfaction through work engagement. Based on the test results, the workplace fun on work engagement (lane a) with a significance value of 0.082 ( $p>0.05$ ), work engagement on job satisfaction (lane b) with a significance value of $0.011(\mathrm{p}<0.05)$, and workplace fun on job satisfaction (path $c$ ) with a significance value of $0.152(\mathrm{p}>0.05)$ so that H06 is accepted and Ha6 is rejected. According to (Baron \& Kenny, 1986), a variable can mediate if the relationship between independent variables on mediation, mediation on the dependent, and independent on the dependent influence each other. Thus, it is stated that work engagement does not mediate in influencing workplace fun on job satisfaction.

A person's engagement in the workplace is shown in three dimensions; passion, dedication, and able to follow the flow of his work. One of the factors that can increase a person's involvement with his work is the support from his work environment, both supervisor or work teams, and how he can control himself in his work environment which will have an impact on motivation, performance, satisfaction in life and work (Bakker, Demerouti, \& Bakker, 2008). In other words, if the above aspects of the work environment are not met, in this case, the support for creating a pleasant work environment has not been fulfilled by the supervisor, it will certainly negatively affect his involvement in the company. In fact, the role of involvement will be very able to increase the job satisfaction of a millennial worker.

\section{Hypothesis 7: The Mediating Role of Work Engagement in relationship Between Meaning of Work toward Job Satisfaction}

The seventh hypothesis stated in the meaning of work has an indirect effect on job satisfaction through work engagement. Based on the test results, the meaning of work on work engagement (lane a) with a significance value of $0.001(\mathrm{p}<0.05)$, work engagement on job satisfaction (lane b) with a significance value of $0.011(\mathrm{p}<0.05)$, and meaning of work on job satisfaction (path c) with a significance value of $0.01(\mathrm{p}>0.05)$ so that it is stated that $\mathrm{H}_{\mathrm{a} 7}$ is accepted and $\mathrm{H}_{07}$ is rejected. Thus, it is stated that work engagement has succeeded in mediating in influencing the meaning of work on job satisfaction. 
Getting meaning from work can lead someone to work better in the form of job satisfaction. Job satisfaction then determines whether people will continue to work or not. The results show that individuals who find meaning will be able to survive well in their work-life (Maharaj \& Schlechter, 2007). The condition of being able to follow the workflow was explained in the dimensions of work engagement in the form of feelings of enthusiasm, dedication, and being able to follow the workflow. (Geldenhuys et al., 2014) research stated that work engagement can be a partial mediation in explaining the relationship between the meaning of work and commitment as part of the outcome of the workplace. In this results

\section{Conclusions}

From the result and discussion above we can see that the results are:

1. Workplace fun does not significantly affect the work engagement of millennial workers in Banda Aceh. This means, increasing millennial workers' work engagement through workplace fun will not have an effect on their work engagement.

2. Meaning of work has a significant effect on the work engagement of millennial workers in Banda Aceh. That is, if millennial workers want to increase their work involvement, it can be done by increasing the meaning of work.

3. Workplace fun has a significant effect on the job satisfaction of millennial workers in Banda Aceh. That is, if the company wants to increase the job satisfaction of millennial workers, it can be done by increasing workplace fun.

4. Meaning of work has no significant effect on job satisfaction of millennial workers in Banda Aceh. That is, the increase in job satisfaction of millennial workers through the meaning of work will not have an effect on their job satisfaction.

5. Work engagement has a significant effect on the job satisfaction of millennial workers in Banda Aceh. That is, if millennial workers and companies want to increase the job satisfaction of millennial workers, it can be done by increasing their work engagement.

6. Work engagement does not mediate in explaining the effect of workplace fun on the job satisfaction of millennial workers in Banda Aceh. This means that work engagement cannot help workplace fun in influencing job satisfaction.

7. Work engagement is a full mediation in explaining the effect of meaning of work on job satisfaction of millennial workers in Banda Aceh. That is, work engagement can help the meaning of work in influencing job satisfaction.

From these results, we can conclude that the model of increasing job satisfaction is a function of increasing work plan fun and work engagement which will directly affect the increase in job satisfaction, and the function of increasing meaning of work which will indirectly affect job satisfaction through work engagement. Academically, this model is a proven combination of causality theory, so that this model of increasing job satisfaction can be developed by further researchers by adding moderating variables such as age or working 
experience. They can also see a difference between millennials living in urban and rural areas. Practically, especially for research subjects, namely millennials in the city of Banda Aceh, policymakers in the workplace such as directors and managers can pay attention to the following.

1. The application of the meaning of work has an effect on work engagement. So it is recommended that the values and influences that have been good should be maintained in order to provide benefits for millennial workers in their future careers.

2. The application of workplace fun has an effect on job satisfaction. So it is recommended that the company maintain a pleasant workplace because it has been proven to have a good effect on the job satisfaction of millennial workers.

3. The application of work engagement has an effect on job satisfaction. So it is recommended that companies maintain good values that meet the expectations and characteristics of millennials in their influence on their job satisfaction because it is a form of good professionalism in the workplace.

4. Work engagement mediates in explaining the effect of the meaning of work on job satisfaction. It is known that workers who can find the meaning of work can survive better in the circle of work, so it is recommended that these good values are maintained so that millennial workers can feel satisfied in their careers.

\section{References}

1) Akgunduz, Y., Alkan, C., \& Gök, Ö. A. (2018). Perceived organizational support, employee creativity and proactive personality: The mediating effect of meaning of work. Journal of Hospitality and Tourism Management, 34, 105-114. https://doi.org/10.1016/j.jhtm.2018.01.004

2) Aleksić, D., \& Rangus, K. (2020). Millennials \& Creativity. Reference Module in Neuroscience and Biobehavioral Psychology, 1-7. https://doi.org/10.1016/b978-0-12809324-5.23869-8

3) Bakker, A. B., Demerouti, E., \& Bakker, A. B. (2008). Towards a model of work engagement. Career Development International, 13(3), 209-223. https://doi.org/10.1108/13620430810870476

4) Baron, R. M., \& Kenny, D. A. (1986). The Moderator-Mediator Variable Distinction in Social Psychological Research: Conceptual, Strategic, and Statistical Considerations. Journal of Personality and Social Psychology, 51(6), 1173-1182.

5) Becker, F. W., \& Tews, M. J. (2016). Fun activities at work: Do they matter to hospitality employees? Journal of Human Resources in Hospitality and Tourism, 15(3), 279-296. https://doi.org/10.1080/15332845.2016.1147938

6) Bilginoğlu, E. (2020). Debunking the myths of workplace fun. Middle East J. of Management, 7(2), 150. https://doi.org/10.1504/mejm.2020.105945

7) Budiati, I., Susianto, Y., Adi, W. P., Ayuni, S., Reagan, H. A., Larasaty, P., ... Saputri, V. G. (2018). Statistik Gender Tematik, Profil Generasi Milenial Indonesia. Jakarta: KPP 
dan PA dan BPS.

8) Chan, S., \& Mak, W. (2016). Have you experienced fun in the workplace? An empirical study of workplace fun, trust-in-management, and job satisfaction. Journal of Chinese Human Resource Management, 7(1), 27-38. https://doi.org/https://doi.org/10.1108/JCHRM-03-2016-0002

9) Clancy, M., \& Linehan, C. (2019). Modelling the subjective experience of fun at work. Employee Relations, 41(3), 520-537. https://doi.org/10.1108/ER-10-2017-0251

10) Diener, E., Suh, E. M., Lucas, R. E., \& Smith, H. L. (1999). Subjective well-being: Three decades of progress. Psychological Bulletin, 125(2), 276-302. https://doi.org/https://doi.org/10.1037/0033-2909.125.2.276

11) Fluegge-Woolf, E. R. (2014). Play hard, work hard: Fun at work and job performance. Management Research Review, 37(8), 682-705. https://doi.org/10.1108/MRR-11-20120252

12) Ford, R., McLaughlin, F., \& Newstrom, J. (2003). Questions and answers about fun at work. People and Strategy, 26(4), 18.

13) Geldenhuys, M., Łaba, K., \& Venter, C. M. (2014). Meaningful work, work engagement and organisational commitment. SA Journal of Industrial Psychology, 40(1), 1-10. https://doi.org/10.4102/sajip.v40i1.1098

14) Georganta, K., \& Montgomery, A. (2019). Workplace fun: a matter of context and not content. Qualitative Research in Organizations and Management: An International Journal, 14(3), 317-336. https://doi.org/10.1108/QROM-06-2017-1541

15) Hackman, J. R., \& Oldham, G. R. (1980). Work Redesign. United States: AddisonWesley.

16) Harpaz, I., \& Fu, X. (2002). The structure of the meaning of work: A relative stability amidst Human Helations, 55(6), 639-667. https://doi.org/10.1177/0018726702556002

17) Jung, H. S., \& Yoon, H. H. (2016). What does work meaning to hospitality employees? The effects of meaningful work on employees' organizational commitment: The mediating role of job engagement. International Journal of Hospitality Management, 53, 59-68. https://doi.org/10.1016/j.ijhm.2015.12.004

18) Karatepe, O. M., \& Karadas, G. (2016). Service employees' fit, work-family conflict, and work engagement. Journal of Services Marketing, 30(4), 554-566. https://doi.org/10.1108/JSM-02-2015-0066

19) Karl, K. A., \& Peluchette, J. V. (2006). Does Workplace Fun Buffer the Impact of Emotional Exhaustion on Job Dissatisfaction?: A Study of Health Care Workers. Journal of Behavioral and Applied Management, 7(2), 128-141. https://doi.org/10.21818/001c.16553

20) Luthans, F. (2002). Positive organizational behavior: Developing and managing psychological strengths. Academy of ManagemenI Executive, 16(1), 57-72.

21) Maharaj, I., \& Schlechter, A. F. (2007). Meaning in life and meaning of work: 
Relationships with organisational citizenship behaviour, commitment and job satisfaction. Management Dynamics, 16(3), 24-41.

22) Oshagbemi, T. (1997). Job satisfaction and dissatisfaction in higher education. Education + Training, 39(9), 354-359. https://doi.org/https://doi.org/10.1108/00400919710192395

23) Perrin, B. (1998). Effective Use and Misuse of Performance Measurement. American Journal of Evaluation, 19(3), 367-379. https://doi.org/10.1016/S1098-2140(99)80218-5

24) Rosso, B. D., Dekas, K. H., \& Wrzesniewski, A. (2010). On the meaning of work: A theoretical integration and review. Research in Organizational Behavior, 30, 91-127. https://doi.org/https://doi.org/10.1016/j.riob.2010.09.001

25) Schaufeli, W. B., Bakker, A. B., \& Salanova, M. (2006). The measurement of work engagement with a short questionnaire: A cross-national study. Educational and Psychological Measurement, 66(4), 701-716. https://doi.org/10.1177/0013164405282471

26) Shanock, L. R., \& Eisenberger, R. (2006). When supervisors feel supported: Relationships with subordinates' perceived supervisor support, perceived organizational support, and performance. Journal of Applied Psychology, 91(3), 689-695. https://doi.org/https://doi.org/10.1037/0021-9010.91.3.689

27) Spector, P. E. (1985). Measurement of human service staff satisfaction: Development of the Job Satisfaction Survey. American Journal of Community Psychology, 13(6), 693713. https://doi.org/10.1007/BF00929796

28) Tews, M. J., Michel, J. W., \& Allen, D. G. (2014). Fun and friends: The impact of workplace fun and constituent attachment on turnover in a hospitality context. Human Relations, 67(8), 923-946. https://doi.org/10.1177/0018726713508143

29) Tsaur, S. H., Hsu, F. S., \& Lin, H. (2019). Workplace fun and work engagement in tourism and hospitality: The role of psychological capital. International Journal of Hospitality Management, $\quad$ 81(February), $131-140$. https://doi.org/10.1016/j.ijhm.2019.03.016

30) Wong, I. K. A., Wan, Y. K. P., \& Gao, J. H. (2017). How to attract and retain Generation $\mathrm{Y}$ employees? An exploration of career choice and the meaning of work. Tourism Management Perspectives, 23, 140-150. https://doi.org/10.1016/j.tmp.2017.06.003

31) Yalabik, Z. Y., Rayton, B. A., \& Rapti, A. (2017). Facets of job satisfaction and work engagement. Evidence-Based HRM, 5(3), 248-265. https://doi.org/10.1108/EBHRM-082015-0036

32)Zika, S., \& Chamberlain, K. (1992). On the relation between meaning in life and psychological well-being. British Journal of Psychology, 83(1), 133-145. https://doi.org/https://doi.org/10.1111/j.2044-8295.1992.tb02429.x 